\title{
ECONOMIC GROWTH AND
} MACROECONOMIC DYNAMICS IN NIGERIA

\author{
Johnson Babatunde Solomon, Onakoya Adegbemi \\ Babatunde, Akeju Olufemi
}

(1) Department of Economics, Babcock University, Ilishan - Remo, Nigeria

(2) Department of Economics, Babcock University, Ilishan - Remo, Nigeria (3) Department of Banking and Finance, Babcock University, Ilishan - Remo, Nigeria

Johnson Babatunde Solomon Department of Economics, Babcock University, Ilishan - Remo, Nigeria tundesolomonjohnson@yahoo.com

Article info Paper category: Preliminary paper Received: 11.8.2018. Accepted: 28.9.2018. JEl classification: $\mathrm{O}_{4} \mathrm{O}, \mathrm{E}_{1}, \mathrm{O}_{24}, \mathrm{E}_{4}, 3, \mathrm{E} 61, \mathrm{E}_{24}$

Keywords Economic Growth (GDP); Exchange Rate; Inflation rate; Interest rate; Unemployment Rate 


\begin{abstract}
Purpose. The role of macroeconomic variables in shaping the economic status has been debated in the literature. The management of these factors has been epileptic and sometimes contradictory with consequential implications for sustainable economy. This study therefore examined the relative significance of macroeconomic factors (inflation rate, interest rate, exchange rate and unemployment rate) on current national income. In addition, it sought to ascertain the relative importance of prior income (past GDP) on current national income (current GDP) based on data obtained between 1975 and 2015.
\end{abstract}

Methodology. The study deployed pre-estimation descriptive statistics and stationarity tests using the Augmented Dickey Fuller test and Phillip Perron tests. Johansen cointegration test was applied for establishing the long run relationship of the variables. The final phase is the post estimation tests to confirm the robustness of the estimated model. These are the Breusch-Godfrey test to check for any form of auto correlation among the variables, the heteroskedasticity test and the Impulse Response analysis of the dependent variable with respect to shocks in the explanatory variables.

Findings. The result findings revealed that inflation contributes negatively to economic growth. Interest rate, exchange rate and unemployment impact economic growth positively. The entire explanatory variables have no short-run effect. The result of the Breusch-Godfrey LM and Breusch-Pagan-Godfrey test indicated the absence of serial correlation and heteroscedasticity respectively. In effect, by itself, macroeconomic stability does not guarantee sustainable high rates of economic growth in the absence of key institutional and structural measures. The study recommended diversification of the economy and the use of inflation targeting which would be commensurate with the level of economic growth should be pursued by policy makers

Limitations. This research examined the impact of the various macroeconomic variables on the economy over a period of 41 years. A structural break analysis of the impact before and after major policy shifts like StructuralAdjustment Programme (1986), Financial Sector reform (2004), Global Financial Crisis (2007 - 2008) etc. should be explored by new studies.

Originality. This study is an original work. It has not been published in any other journal and is not being considered for publication by another channel 


\section{INTRODUCTION}

The debate on the key drivers of economic growth has been ongoing and it is still far from over (Nihat, Ali \&Emrah, 2013; Mbulawa, 2015; Obrimah, 2015). Indeed, the role of macroeconomic stability through stable prices (low inflation), low levels of debt (whether foreign or domestic), free market economy, low levels of unemployment, is considered crucial in engendering sustainable economy (Mbulawa, 2015).

The macroeconomic variables have manifested epileptic variations. The inflation levels in Nigeria moved down from $18 \%$ in 2005 to about $12 \%$ in $2012,11.92 \%$ in 2014 and $8.5 \%$ in 2013 . However, interest rate in Nigeria which has the ability to impact on the level of investment and availability of credit in the country has averaged about $10.24 \%$ from 2010 to 2015 following a record low of $6 \%$ in July 2009 (Trading Economics, 2016). The increase in interest rates attracted the inflow of foreign capital into the country. The sustained dependence on foreign capital over a long period of time has been associated as one of the major causes of a decline in the value of the local currency, the Naira. The import dependency on consumables, machinery and spare parts, led to increased level of inflation.

The lack of synergy between the level of inflation and the cost of borrowing funds represented coupled with the value of the local currency contributed to the increased unemployment rate from $7.8 \%$ in 2014, to $9.0 \%$ in (Trading Economics, 2016). The increase in the level of unemployment has been associated to loss of jobs as various companies in different industries have been involved in massive retrenchments due to the uncertainty of the economic environment in the country.

The effect of the variations in unemployment rate, interest rate, exchange rate and inflation rate has had an impact on the environmental conditions of the household, firms and government. The result of the increase in the dependence on foreign capital coupled with the fact that Nigeria depends majorly on imports impacted on the ability of the household to buy goods and services as prices for commodities were high which thus reduced the purchasing power of the household. This also affected the level of savings of the domestic household, as increasing interest rates and its associated features discouraged consumption and thus impacted on the level of earnings of the firms as profit dropped which led to a mass retrenchment of workers in 2015.

Efforts by the monetary authority, the Central Bank of Nigeria (CBN) to curtail inflation by increasing interest rate shrinks the ability of the financial sector to create more money through loans and which thus contributed negatively to growth. In the same vein, the increasing level of interest rate has failed to suppress the level of inflation, as the Nigerian economy is largely import dependent. Efforts by the monetary authority to improve the value of Naira through increased interest rate has not strongly succeeded in attracting foreign investment into the Nigerian economy. These dynamics requires further investigation which necessitated the conduct of this research. 
The objective of the study is therefore to evaluate the relative significance of macroeconomic factors (inflation rate, interest rate, exchange rate and unemployment rate) on current national income. In addition, ascertain the relative importance of prior income (past GDP) on current national income (current GDP). The balance of this study is as follows: In the next section, the review of previous works is presented. In the third and fourth sections, the methodology of research and the findings are discussed. The last section covers both recommendations and conclusions.

\section{REVIEW OF LITERATURE}

The review of previous works is in two parts: theoretical and empirical.

\subsection{Theoretical Review}

This section examines the theories upon which this research is predicated. There is a plethora of theories propounded with respect to the macroeconomic variables. The classical growth theory of Adam Smith and Malthus sees the rate of investment as the main factor that fosters economic growth. The Harrod-Domar growth theory carries implications for less economically developed countries (LDCs) for which Nigeria can be categorized, where labor is in plentiful supply in these countries, but physical capital is not, slowing down economic progress. The Augmented Solow theory (1956) posits that economic growth is a product of technological progress and is useful for estimating the separate effects of technological change, capital and labor on economic growth. Developing countries do not have sufficiently high incomes to enable sufficient rates of saving; therefore, accumulation of physicalcapital stock through investment is low.

The endogenous growth theory articulated by Romer (1986 and 1990) and Lucas (1988) assumes that production function does not exhibit diminishing returns to scale due to the beneficial effect positive spillovers from capital investment to the economy as a whole or improvements in technology which leads to further improvements as a result of learning curve. Like the Solow model, it considers capital accumulation an important factor, technological advancement is seen as a key driver of economic growth within the economy. This theory however has not explained conditional convergence and the income differences between developed countries and developing countries.

The relevant theories of interest rate in the study include the loanable funds and the Keynesian theory of interest. The loanable fund theory holds that economic activities are guided by some invisible hands that is the self-interest and price mechanism (Wicksell, 1898). The relevance of this theory to this research is borne out of the need to explain movements in the general level of interest rates in Nigeria and 
why interest rates among debt securities of a given country vary. The Marxist theory supports the Keynesian theory but suggests that the market system's propensity to cut wages and reduce labor participation on an enterprise level causes a requisite decrease in aggregate demand in the economy. This increases unemployment and increases the periods of low economic activity before the capital accumulation (investment) phase of economic growth can continue.

The post-Keynesian endogenous theory of money by Kaldor (1970) negates the contention of the monetarists that the Central Bank exogenously determined money supply and therefore its direct impact on the price level in the economy. For Kaldor, the dependent variable is actually the supply of money which is determined by the price level as dictated by the level of money wage rates. The rational expectation approach was postulated by Lucas (1972). It states that the forward-looking expectation adjustments of economic agents will ensure that the pre-announced policy fails where the people are able to anticipate such policy announcements.

The Phillips curve established a trade-off between unemployment and inflation. Prior to the emergence of the Phillips curve, both Keynesian and the Monetarists failed to examine the nexus between inflation and unemployment which were treated as different subjects. Specifically, the Phillips curve tried to determine whether the inflation-unemployment link was causal or simply correlational. However, Friedman (1956) disapproved Phillip's curve thesis, stating that the trade-off between unemployment and inflation only existed in the short-run and that in the long-run, the Phillips curve is vertical. This is because in the long run, workers and employers will take inflation into account, resulting in employment contracts that increase pay at rates near anticipated inflation. In Nigeria, rising inflation rate without a corresponding increase in the wage level of workers has led to a drop in the growth rate in the economy. This rise in inflation can be traced to high interest rates and the falling value of the naira against the dollar.

According to the Okun's law (1962), an increase in unemployment rate will lead to a decline in the potential growth which is to be achieved by the economy, thus an inverse relationship exists between unemployment and economic growth. The new Keynesian theory is however of the view that the labor union is allowed to determine the equilibrium employment level in the economy while the government acts as a moderator to activities in the labor sector. The Structural Inflation theory by Myrdal (1968) suggests that supply increases in relation to demand-push, even if abundant unemployment of production factor is impossible or slow.

The purchasing power parity propounded by Cassel (1918), states that the exchange rates between currencies are in equilibrium when purchasing power is the same in each of the two countries. The theory assumes that the actions of importers and exporters motivated by cross country price differences, induces changes in the spot exchange rate, and consequently the shifts in the term of trade, which ultimately influence economic growth. However, in practice the real exchange rates exhibit 
both short run and long run deviations from this value, for example due to reasons illuminated in the Balassa-Samuelson theorem. The Keynesian absorption approach posits that devaluation increases exports and reduces imports thus impacting positively on the national income of a country which would affect positively the domestic consumption. This can further lead to the economic growth of a country. Within the context of the falling exchange rate in Nigeria which is linked to over-reliance on importation, the assumptions of the absorption approach may be adopted by promoting exportation and reducing importation which can help to stir growth in the economy.

These theories underline the dynamic nature of the variations in the various macroeconomic variables. The next discussion on previous studies is presented in the next section.

\subsection{Review of Empirical Literature}

\subsubsection{Developed Countries}

The study by Eichengreen (2008) examined real exchange rate and economic growth using descriptive analysis and panel data regression analysis obtaining data from 1985-2003 and found that real exchange volatility appears to have a significantly negative impact on employment growth. Similar study and method by Jinzhao (2012) confirmed same result in China. The unemployment hysteresis in the USA was studied by Rosoiu (2014) using the Kwiatkowski-Phillips-Schmidt-Shin (KPSS) tests in the confirmation of the Okun's Law.

Chang-Shuai and ZI-Juan (2012) carried out a study on the relationship among Chinese Unemployment rate, economic growth and inflation using the VAR and ECM between $197^{8}$ and 2010 and concluded that there is a long-term stable equilibrium relationship among the variables unemployment, inflation and economic growth. However, in the short term, economic growth is positive correlated with unemployment rate while inflation and unemployment rate are negative correlated with inflation. Evidence gathered by Qin and Wang (2013) in a study on inflation rate and unemployment rate points out that causal relationship between the inflation rate and unemployment rate in China is ineffective.

\subsubsection{Developing and Emerging Economies}

Antwi, Mills and Zhao (2013) studied the impact of macroeconomic factors on economic growth in Ghana. The researchers employed error correction model (ECM) and carried out tests such as Augmented Dickey Fuller (ADF), Johansen cointegration and found that long run economic growth in Ghana is explained by physical capital, foreign direct investment, foreign aid, inflation and government expenditure. Yet, Kira (2013) found that some variables were inactive such as Investment 
and Imports indicating that their influence on GDP is not significant. While Taylan (2012) when examining macroeconomic variables and unemployment in Turkey, applied the Vector Autoregressive model (VAR). It found that positive shocks to growth, growth in exports and inflation reduce unemployment. Also, shocks to interbank interest rate, exchange rate and money supply increase unemployment. Contradictory results are obtained with the interbank interest rate shocks by Shatha, Thikraiat, and Ruba (2014) for a cross section of nine Arab countries comprising of Egypt, Tunisia, Algeria, Sudan, Morocco, Lebanon, Syria, Palestine and Jordan.

Thayaparan (2014) examined the impact of inflation and economic growth on unemployment in Sri Lanka using ADF and Granger causality tests. Results shows that coefficient of inflation is negative and statistically significant on unemployment whereas GDP although positive, has no significant effect on unemployment. Madito and Khumalo (2014) investigation of the nexus between economic growth and unemployment in South Africa using the vector error correction model (VECM) found reversed relationship between the variables in South Africa. This was contradicted by Al- Habees and Rumman (2012) in Jordan and Lavinia, Barbu, and Silvia (2013) in Romania.

Brigitta (2015) analyzed the impact of exchange rate regimes on economic growth sourcing data from seventy-four countries comprising majorly of developing countries. The researcher used a combination of both descriptive analysis and a multiple regression model to analyze his results and it was found that there is indeed a significantly positive correlation between fixed regimes and economic growth, by using inflation rate and gross capital formation as a percentage of GDP as the control variables. This evidence was in agreement with the findings in Livio, Elitza and Maurizio (2016) who carried out a review on the real exchange rate and economic growth using external instruments with data gotten from over a hundred and fifty countries comprising majorly of developing countries. Qaisir, and Kasim (2009) further investigated the non-linearity between inflation rate and GDP growth in Malaysia using autoregression (TAR) points to the fact that the relationship between inflation rate and economic growth is nonlinear.

Contrarian findings was recorded by Khan and Senhadji (2011). The Saymeh and Orabi (2013) review of the effect of interest rate, inflation rate, GDP on real economic growth rate in Jordan using the GARCH model indicated that inflation causes interest rate and that on the other hand all other variables (Real GDP, nominal GDP) are independent of each other. This is also different from Hussain and Shahnawaz (2011) evidence from Pakistan. Indeed, Limam (2015) found unidirectional causality running from inflation to economic growth in Mauritania. This was contradicted by the findings of Mbulawa (2015) in Zimbabwe. Other researches include Agalega and Antwi (2013) in Ghana, contradicted by the findings of Chugtai, Malik and Aftab $(2015)$ in Pakistan. However, Tridico (2013) findings were different. While studying the determinants of economic growth in emerging economies using OLS, carrying 
out the granger causality test and correlation matrix, he found both human capital and export capacity are important for economic growth.

\subsubsection{Empirical Evidence in Nigeria}

Adeniran, Yusuf and Adeyemi (2014) investigated the impact of exchange rate fluctuation on the Nigerian economic growth using OLS method, correlation and regression analysis and found that interest rate and rate of inflation have negative impact on economic growth, but this is not so significant. Also found was that exchange rate has positive but not significant impact on economic growth. This was supported by Rasaq (2013) and Obrimah (2015). Contrary findings were reported by, Azeez and Kolapo (2012) and Okorontah and Odoemena (2016).

However, Nwoye, Obiorah and Ekesiobi (2015) inquired about the effect of Nigeria's macroeconomic environment on the performance of the national economy. Using the OLS method and found that unique relationship exists between the country's national currency exchange rate to a US dollar, inflation rates, monetary policies, and the extent or level of GDP growth the country. Agwu (2014) obtained a different result while carrying out a survey on factors that contribute to economic growth in Nigeria with data for the period between 1981 and 2012 using the VECM model.

Omoke (2010) inquired on the effect of interest rate fluctuation on the economic growth of Nigeria between 1970-2010 using the OLS method and obtained evidence that there existed an inverse relationship between interest rate and economic growth in Nigeria. These findings were supported by Babalola, Danladi, Akomolafe and Ajiboye (2015), and Shuaib, Augustine and Ogedengbe (2015). Akeju and Olanipekun (2014) examined unemployment and economic growth in Nigeria through the use of ECM and Johansen Co-Integration test with data set from 1980-2010. The evidence of the study revealed a there is both the short and the long run relationship between unemployment rate and output growth in Nigeria. Yet, Arewa and Nwakanma (2012) and Oloni (2013) had come to a different conclusion.

Arising from the literature review, contradictions exist. Several researches considered the variables of interest individually in relation to economic growth and where such researches have considered an aggregation of these variables some did not capture all the variables of interest in their various researches. This study will bring the various variables of interest (inflation rate, interest rate, exchange rate, unemployment rate) with the aim of evaluating whether or not these variables drive economic growth measured by GDP or whether current growth (current GDP) is driven by past income (prior GDP). 


\section{METHODOLOGY}

The ex-post facto design was adopted in evaluating the relationship amongst the macroeconomic variables (inflation, interest rate, exchange rate and unemployment) and the lagged economic growth in Nigeria. The study which covers forty years from 1976 to 2015 is broad enough to capture major economic trade cycles. Data was sourced from several CBN statistical bulletin and the World Bank data.

\subsection{Theoretical Framework and Model Specification}

Arising from the multiplicity of theories underlining the macroeconomic variables, as presented in section 2, this research is predicated on Keynesian IS-LM framework which links both the Augmented Solow growth theory and the endogenous growth theory. The former considers investment in human capital as a driver for economic growth which can be achieved through capital accumulation. For capital to be acquired however, the decisions made as regards to interest rate have to be reasonable as it determines the kind of capital that is existent in an economy (whether it is domestic or foreign). Reduction in interest rates triggers inflation and affects the level of investment as people have more capital to purchase goods and services and employment level. This is captured in the liquidity and price puzzles of the Keynesian IS-LM framework. The endogenous growth model also follows a similar manner as the augmented Solow growth model. According to this model, capital accumulation is key for economic growth, but much emphasis is placed on technological progress. The Solow growth model and its augmented version as denoted by Mankiw, Romer and Weil (1992) is presented as:

$$
\begin{aligned}
\ln Y_{t}-\ln Y_{0}= & -\ln Y_{0}\left(1-e^{-\lambda t}\right)+\ln A_{t}\left(1-e^{-\lambda t}\right)+\left(1-e^{-\lambda t}\right) \frac{u}{1-\alpha-\beta} \operatorname{lns}_{k}+ \\
& \left(1-e^{-\lambda t}\right) \frac{\beta}{1-\alpha-\beta} \ln s_{h}-\left(1-e^{-\lambda t}\right) \frac{\alpha+\beta}{1-\alpha-\beta} \ln (n+g+\delta)
\end{aligned}
$$

Where: economic growth as measured by differences in output $(Y)$ is determined by the level of technology $\left(A_{t}\right)$, the rate of technological progress $(g)$, the initial output per worker $\left(y_{0}\right)$, the savings rate $\left(s_{k}\right)$, the share of capital in output $(\alpha / \beta)$, the rate of convergence to the steady state $(\lambda)$, the depreciation rate $(\delta)$, the growth of labor force $(n)$ and investment in human capital $\left(s_{\mathrm{h}}\right)$.

The applied estimation model for this research is adapted from the work of Onakoya, Fasanya and Agbojuale (2013). The original model made use of the Keynesian IS-LM framework with consideration given to the liquidity puzzle, the price puzzle and the exchange rate puzzles. The original model used in the work is given as: $\Delta \mathrm{GDP}=\alpha_{0}+\alpha_{1} \Delta \mathrm{GDP}_{\mathrm{t}-1}+\alpha_{2} \Delta \mathrm{M} 2_{\mathrm{t}-1}+\alpha_{3} \Delta \mathrm{IR}_{\mathrm{t}-1}+\alpha_{4} \Delta \mathrm{INF}_{\mathrm{t}-1}+\alpha_{5} \Delta \mathrm{REER}_{\mathrm{t}-1}+\alpha_{6}$ $\Delta \mathrm{ER}_{\mathrm{t}-1}+\mathrm{Ut}$ 
Where $\alpha_{1}, \alpha_{2,} \alpha_{3,} \alpha_{4}, \alpha_{5}, \alpha_{6}$ are parameters for GDP, money supply, interest rate, inflation rate, real exchange rate and external reserve.

The adapted model eliminates external reserve and money supply and incorporates unemployment rate. For the purpose of this research, the model to be adopted is specified as

$\ln G D P_{t}=\beta_{0}+\beta_{1} \ln I N F_{t-1}+\beta_{2} \ln I N T_{t-1}+\beta_{3} \ln E X C_{t-1}+\beta_{4} \ln U N E M P_{t-1}+\mathrm{Ut}$

Where $\beta_{\circ}, \beta_{1}, \beta_{2} \beta_{3}, \beta_{4}$ and $\beta_{5}$ are parameters of the model which are economic growth (GDP), interest rate (INT), exchange rate (EXC) and unemployment rate (UNEMP) respectively; $\mathrm{U}_{\mathrm{t}}$ is the disturbance term.

\subsection{Method of Data Analysis}

This study deployed a three-prong approach in the estimation process. The first step is the determination of the distribution normality of the variables using descriptive statistics. This is followed by the testing of the stationarity. A stochastic process is said to be stationary if its mean and variance are constant over time and the value of covariance between two time periods depends only on the distance or lag between two time periods and not on the actual time at which the covariance is computed. The Augmented Dickey Fuller (ADF) and Phillip-Perron (PP) tests are applied in order to avoid spurious regression results.

The second phase is to determine the presence of long-term cointegrating equation among the variables specified in the model using the Autoregressive Distributed Lag (ARDL). This is after determining the appropriate Lag Length using the likelihood ratio (LR) test. The selection of appropriate lag length ensures that the residuals do not have significant autocorrelation which may lead to inconsistent least square estimates (Enders, 1995). The study will deploy the LR test with Schwarz Information Criterion (SIC) as well as Akaike Information Criterion (AIC) statistics. These lag selection criteria enable one to select the smallest lag order without impairing on the degrees of freedom. The Vector Error Correction Model will be estimated to determine the short-run relationship. The Bounds test will be conducted to know the long run relationship of the variables. The Toda Yamoto Causality test to understand the direction of causality

The final phase is the post estimation tests to confirm the robustness of the estimated model. These are the Breusch-Godfrey test to check for any form of auto correlation among the variables, the heteroskedasticity test and the Impulse Response analysis of the dependent variable with respect to shocks in the explanatory variables. Given the possibility of existence of multicollinearity because of the nature of time series, which may affect the validity of the estimated result, the study will strive to reduce its effect by using the centered values of the variables. This will be done by computing the mean of independent variable, and then replacing each value with the difference between it and the mean $(\mathrm{Y}-\overline{\mathrm{Y}})$. The use of the E-views as an estimation 
tool will be deployed to remove the collinear variable from the analysis. Results obtained was tested for compliance with economic theory

\section{FINDINGS AND DISCUSSIONS}

\subsection{Preliminary Analyses}

This section covers the descriptive statistics and stationarity test which are presented in turns.

\subsubsection{Descriptive Statistics}

The series descriptive statistics are presented in Table 1.

Table 1.: Descriptive Statistics of the Variables

\begin{tabular}{|l|r|r|r|r|r|}
\hline STATISTIC & LNGROSSDP & \multicolumn{1}{c|}{ INF } & \multicolumn{1}{c|}{ INTR } & \multicolumn{1}{c|}{ LNEXC } & \multicolumn{1}{c|}{ UNEMP } \\
\hline Mean & 31.04 & 19.89 & 13.29 & 3.75 & 10.89 \\
Median & 30.82 & 11.90 & 10.28 & 4.67 & 11.15 \\
Maximum & 31.88 & 72.84 & 43.57 & 5.54 & 27.40 \\
Minimum & 30.36 & 5.38 & 0.37 & 0.11 & 1.80 \\
Std. Dev. & 0.51 & 18.66 & 11.19 & 1.52 & 7.65 \\
Skewness & 0.42 & 1.57 & 1.25 & -0.82 & 0.65 \\
Kurtosis & 1.60 & 4.044 & 3.95 & $2.5^{3}$ & 2.34 \\
Jarque-Bera & 3.52 & 14.56 & 9.51 & 3.92 & 2.81 \\
Probability & 0.171 & 0.001 & 0.008 & 0.141 & 0.245 \\
\hline
\end{tabular}

Source: Authors' computation using E-views 8.० (2018).

The preliminary data and summary of the statistics of the variables were presented in Table 1. The large difference between the minimum and maximum values of the series gave the result that there is a significant variation in the trends of the variable over the period of consideration. Also, the results based on the statistical distribution of the series shows that the series are positively skewed except exchange rate.

The values, Exchange Rate, Gross Domestic Product, and Unemployment Rate are platykurtic in nature since their values for kurtosis is $2.5^{3,1.60}$ and 2.34 respectively and are less than 3 thus indicates a higher than normal distribution. The variable, Inflation Rate and Interest rate has 4.04 and 3.95 as a result which signifies that it is leptokurtic because it is greater than 3 indicating a flatter than normal distribution. The Jacque-Bera statistics is a goodness of fit to check whether the sample data have the skewness and kurtosis matching a normal distribution. The result shows 
that there is non-normality in all the variables because all the variables are greater than the standard threshold of 2 .

\subsubsection{Stationarity Test Results}

The unit root test results are presented in Table 2.

Table 2.: Unit Root Test Results: Augmented Dickey Fuller Test and Phillip Perron est

\begin{tabular}{|c|c|c|c|c|c|}
\hline \multirow[t]{2}{*}{ Series } & \multicolumn{2}{|c|}{ Augmented Dickey Fuller } & \multicolumn{2}{|c|}{ Phillip Perron } & Order of \\
\hline & $\begin{array}{r}\text { Critical Value } \\
5 \%\end{array}$ & $\begin{array}{r}\text { Test at first } \\
\text { difference } \\
\text { (Prob.) }\end{array}$ & $\begin{array}{r}\text { Critical Value } \\
55^{\%}\end{array}$ & $\begin{array}{r}\text { Test at first } \\
\text { difference } \\
\text { (Prob.) }\end{array}$ & \\
\hline LNGDP & -2.96 & $-4.31(0.00)$ & -2.96 & $-4.9^{8}(0.00)$ & $\mathrm{I}(1)$ \\
\hline INF & -2.98 & $-3.64(0.01)$ & -2.96 & $-6.10(0.00)$ & $\mathrm{I}(1)$ \\
\hline INT & -2.98 & $-4.95(0.00)$ & -2.95 & $-6.60(0.00)$ & $\mathrm{I}(1)$ \\
\hline LNEXC & -2.97 & $-4.99(0.00)$ & -2.96 & $-12.07(0.00)$ & $\mathrm{I}(1)$ \\
\hline UNEMP & -2.96 & $-5.47(0.00)$ & -2.96 & $-4.27(0.00)$ & $\mathrm{I}(1)$ \\
\hline
\end{tabular}

Source: Authors computation using E-Views 8.० (2018).

The application of Augmented Dickey Fuller test and Phillip Perron test shows all the variables stationary at first the difference meaning the use of the Ordinary Least Square (O.L.S) estimation technique is unsuitable. The Johansen cointegration test is applied for determining the long-run relationship amongst the variable. This method as designed by Johansen (1988) and Johansen and Juselius (1990) are based on an unrestricted vector autoregressive (VAR) model which is specified in the form of error-correction model. Prior to this estimation, the optimal lag length will have to be calculated because the cointegration technique is lag sensitive.

\subsection{Estimation Results}

\subsubsection{Optimal Lag Length Selection}

The lag selected length expounds the consequential implication of the previous year's result of previous year on the current year. The result is provided in Table 3.

Table 3.: Optimal Lag Length Selection Criteria

\begin{tabular}{|c|r|r|r|r|r|r|}
\hline Lag & \multicolumn{1}{c|}{ LogL } & \multicolumn{1}{c|}{ LR } & \multicolumn{1}{c|}{ FPE } & \multicolumn{1}{c|}{ AIC } & \multicolumn{1}{c|}{ SC } & \multicolumn{1}{c|}{ HQ } \\
\hline 0 & -375.30 & NA & $70,548.03$ & 25.35 & 25.59 & 25.43 \\
1 & -261.73 & $181.71^{*}$ & $197.70^{*}$ & $19.45^{*}$ & $20.85^{*}$ & $19.90^{*}$ \\
2 & -242.38 & 24.52 & 335.22 & 19.83 & 22.39 & 20.65 \\
\hline
\end{tabular}

* indicates lag order selected by the criterion

$H Q=$ Hannan - Quinn information criterion 
$A I C=$ Akaike information criterion

$L R=$ sequential modified LR test statistic (each test at $5 \%$ level)

$S C=$ Schwarz information criterion

FPE = Final prediction error

Source: Authors computation using E-views 8.0(2018).

The different criterion selected disparate optimal levels. As advised the lowest lag length as prescribed by the Schwarz information criteria (1) is selected. The next step in the estimation process - the Co-integration is presented in the next section.

\subsubsection{Cointegration Test Result}

Two kinds of tests considered under the Johansen cointegration technique are the Eigenvalue and Trace statistic tests. The Trace statistics in examining the null hypothesis assumes that the number of distinct cointegrating vectors $(\mathrm{r})$ is more than the $(r)$ against a general alternative. On the other hand, the maximal eigenvalue tests measures $(r)$ against the alternative of $r+1$ cointegrating vectors. The respective equations are as follows:

$$
\begin{aligned}
& \lambda \text { trace }=-\mathrm{T} \sum_{i=r+1}^{n} \ln \left(1-\lambda_{i}^{2}\right) \\
& \lambda \max =-\mathrm{T} \ln \left(1-\lambda_{r+1}\right)
\end{aligned}
$$

Where:

$\lambda_{\mathrm{i}}=$ the estimated values of the ordered eigenvalues

$\mathrm{T}=$ the number of the observations after the lag adjustment.

The Johansen Co-integration result based on hypothesized 5 percent level of acceptance is reported Table 4 .

Table 4.: Result of Johansen Co-integration test based on Trace Statistic and Max Eigenvalue

\begin{tabular}{|l|r|r|r|r|r|r|r|}
\hline $\begin{array}{c}\text { No. of } \\
\text { CE(s) }\end{array}$ & \multicolumn{4}{|c|}{ Trace Statistic } & \multicolumn{3}{c|}{ Max. Eigen Value } \\
\hline value & Eigen & Trace & Critical & Prob.** & Max-Eigen & Critical & Value \\
Value & Prob.** \\
None* & 0.79 & 86.11 & 69.82 & 0.00 & 44.84 & 33.88 & 0.00 \\
At most 1 & $0.5^{3}$ & 41.28 & 47.86 & 0.18 & 21.76 & 27.58 & 0.23 \\
At most 2 & 0.39 & 19.51 & 29.80 & 0.46 & 14.14 & 21.13 & 0.35 \\
At most3 & 0.14 & 5.38 & 15.50 & 0.77 & 4.38 & 14.27 & 0.82 \\
At most 4 & 0.03 & 1.00 & 3.84 & 0.32 & 1.00 & 3.84 & 0.32 \\
\hline
\end{tabular}

Notes:Trace test indicates 1 cointegrating eqn(s) at the 0.05 level

Max-eigenvalue test indicates 1 cointegration at the 0.05 level

* denotes rejection of the hypothesis at the 0.05 level, *MacKinnon-Haug-Michelis (1999) p-values.

Source: Authors computation using E-views 8.o (2018). 
The Johansen co-integration test was optimized at none using both the Trace statistic and Max-Eigen Value respectively which means the absence of a longrun connection between the gross domestic product and inflation rate, interest rate, exchange rate and unemployment rate. The result of the estimated long-run relationship is presented in Table 4 .

\subsubsection{Vector Error Correction Model}

In order to know the existence of possible short-term relationship, the Vector Error Correction Model is estimated. This is done by integrating the multi-variate time series, the dynamics of which assists the maintenance of the equilibrium in the long-run. The result is reported in Table 5 .

Table 5.: Vector Error Correction Model (VECM) Result.

\begin{tabular}{|l|r|r|r|r|r|}
\hline $\begin{array}{c}\text { Error } \\
\text { Correction: }\end{array}$ & D(LNGDP) & D(INF) & D (INTR) & D(LNEXC) & D(UNEMP) \\
\hline CointEq1 & -0.10 & -10.39 & 17.67 & -0.15 & 4.36 \\
s.e. & $(0.04)$ & $(12.52)$ & $(9.58)$ & $(0.22)$ & $(2.88)$ \\
T-stat(Cal) & {$[-2.35]$} & {$[-0.83]$} & {$[1.85]$} & {$[-0.67]$} & {$[1.51]$} \\
\hline
\end{tabular}

Source: Authors computation using E-views 8.o (2018).

The null hypotheses are accepted since the tabulated absolute T-stats value (2.04) is greater than the calculated absolute value INF (0.83), INTR (1.85), LNEXRATE ( 0.67 ) and UNEMP (1.51). This means that no short run association exists among Real Gross Domestic Product and Inflation Rate, Interest Rate, Exchange Rate and Unemployment rate. After normalization with respect to the independent variable, the result of the VECM is presented in Table 6.

Table 6.: Result of Vector Error Correction Model Regression Test

\begin{tabular}{|l|r|r|r|}
\hline \multicolumn{1}{|c|}{ Variable } & $\begin{array}{c}\text { Co-Efficient(After } \\
\text { Normalization) }\end{array}$ & Standard Error & T-Statistic \\
\hline LnGDP & 1.00 & & \\
INF & -0.01 & 0.00 & -3.42 \\
INTR & 0.02 & 0.01 & 2.70 \\
LnEXC & 0.02 & 0.05 & 0.34 \\
UNEMP & 0.06 & 0.01 & 6.30 \\
\hline
\end{tabular}

Source: Authors Computation using E-Views 8.o(2018).

The estimated model is shown in equation 6

$=-0.01 \mathrm{INF}+0.02 \mathrm{INT}+0.02 \mathrm{LnEXC}+0.06 \mathrm{UNEMP}$

R-squared: 0.411 Adjusted R-squared: 0.03 
The equation (6) means that a negative relationship exists between LnGDP and inflation rate. This relationship is statistically significant at 5 percent since the absolute calculated t statistic (3.42) is greater than tabulated t-statistics (2.04). A percentage increase in inflation rate would result in a reduction in $L n G D P$ which corresponds with the apriori expectation and both variables were statistically significant. However, a positive relationship existed amongst LnGDP, INTR, LnEXC and UNEMP and all the variables were statistically significant with LnGDP except LnEXC.

The $\mathrm{R}$-squared is $0.41 \mathrm{~m}$ means that approximately $4_{1} \%$ of the variations in $\operatorname{LnGDP}$ is explained by INF, INTR, LnEXCand UNEMP. The next in the estimation phase is the conduct of some post-estimation tests to check the validity of the model.

\subsection{Post-Estimation Tests}

The results of serial correlation, autocorrelation of the residuals and heteroscedasticity tests are presented in the next sub-sections

\subsubsection{Serial Correlation (Breusch-Godfrey Lm) Test}

The result of the serial correlation test between the variables using the BreuschGodfrey Lm test is in Table 7 .

Table 7.: Serial Correlation (Breusch-Godfrey LM) Test

\begin{tabular}{|l|r|r|r|}
\hline F-statistic & 5.30 & Prob. F $(2,25)$ & 0.00 \\
Obs*R-squared & 0.00 & Prob. Chi-Square (2) & 1.00 \\
\hline
\end{tabular}

Source: Authors computation using E-views 8.० (2018).

The absence of serial correlation is confirmed since the chi-square probability value of 1.00 is greater than the $5 \%$ significance level.

\subsubsection{Heteroscedasticity (Breusch-Pagan) Tests}

The absence of heteroscedasticity is one of the basic assumptions of OLS. The result of the heteroscedasticity is presented in Table 8 .

Table 8.: Result of Breusch-Pagan-Godfrey Heteroscedasticity Test

\begin{tabular}{|l|r|r|r|}
\hline F-statistic & 0.20 & Prob. F (4,26) & 0.94 \\
Obs*R-squared & 0.92 & Prob. Chi-Square (4) & 0.92 \\
Scaled explained SS & 2.22 & Prob. Chi Square (4) & 0.70 \\
\hline
\end{tabular}

Source: Authors computation using E-views 8.० (2018). 
After estimation, result shows that the Probability or P Value of the Obs* Rsquared is 0.94 which is greater than $5 \%$ significance level. In effect, this is the absence of heteroscedasticity.

\subsubsection{Impulse Response Function}

The response of variables to the introduction of shocks assailing the economic system is captured by the impulse response function which describes the impact along a specified time horizon. The response on GDP shock is presented in Figure 1.

Figure 1.: Response of LNGDP to Cholesky One S.D. Innovations

Response of LNGDP to Cholesky

One S.D. Innovations

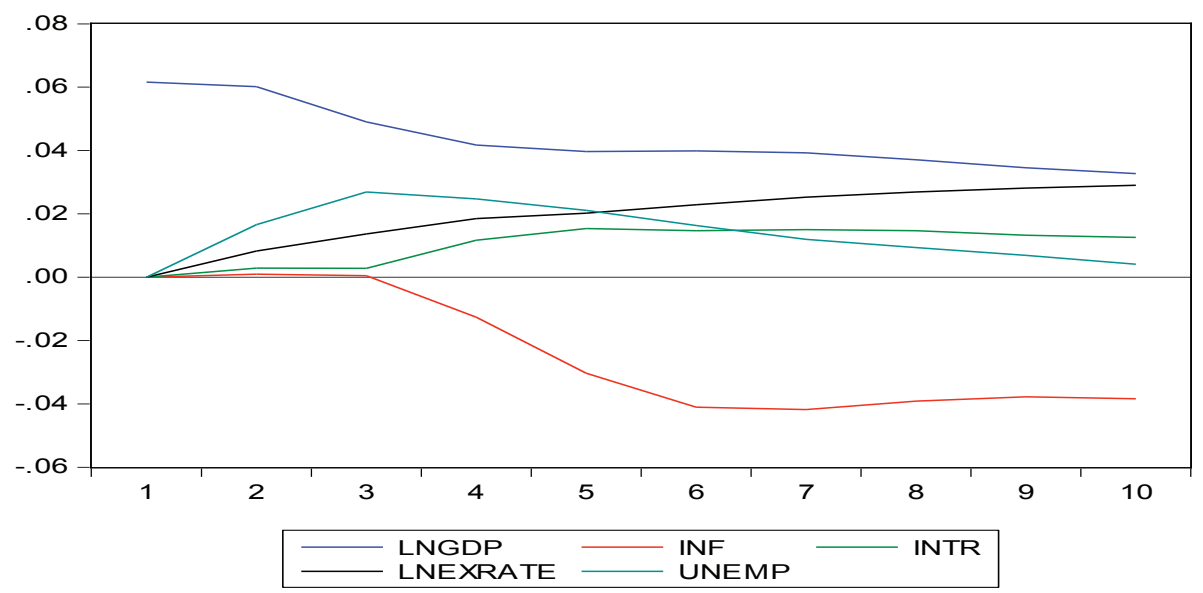

Source: Authors.

The Impulse Response function in Figure 1. corroborates the findings of the Johannsen cointegration test that except for inflation rate, all other macroeconomic variables responded positively to economic shock. One standard deviation positive shock of GDP caused inflation level to fall from the first year and drastically from the third year.

\subsection{Discussion of Findings}

The review of each of the macroeconomic variables reveals mixed results. Whereas a negative relationship existed between inflation and economic growth, the contrary nexus obtained for interest, exchange and unemployment rates. The underlining theories for the research are the Augmented Solow growth and the 
Endogenous growth theories. Both theories were linked to the Keynesian IS-LM framework which was the original theory for which the model adapted for this study was based on.

In the case of Inflation, the influence of inflation economic growth is widely debated. Contrary to the findings of Mallik and Chowdhury (2001) and Ojonye (2015) but in line with the findings of Babalola et al (2015) the presence of inflation negatively influences the growth of an economy. The inflation-growth effect is however non-linear. As postulated by Gillman, Harris and Mátyás, (2000) when the level of the rate of inflation rises above a certain high threshold, the impact falls monotonically until the effect is nil. Thereafter, the effect turns positive. In essence, the impact of rising inflation becomes marginally stronger at zero nominal rate of interest and increasingly manifest in small magnitude with it rises.

The inflation rate as the last quarter of 2016 stood at about $18.3 \%$ as a result of the target level of inflation by the Central Bank of Nigeria. Indeed, this high level of inflation is coupled with high unemployment rate. The latter was $10.63 \%$ on the average from 2006 until 2016. The unemployment rate reached an all-time height of $19.70 \% 2009 \mathrm{Q}_{4}$ and lowest value of $5.10 \%$ in $2010 \mathrm{Q}_{4}$ (Trading Economics, 2016). This stagflation condition of simultaneous increase in both inflation and unemployment provides explanation for the deleterious impact of inflation on the economic growth.

The results of the study conform to the predictions of the Augmented Solow growth and Endogenous growth theories on interest rate, as the current value of interest rate, its two to three past period values impacted positively on the growth of the Nigerian economy. (Figure 1 - Impulse Response Function). The one period value contributed positively on economic growth to the tune of $0.02 \%$. The result of the study thus confirms that increasing level of interest rate is desirable but needs to be synchronized with other monetary and fiscal policies to drive economic growth.

In the case of exchange rate, it is viewed that in the short run, increasing level of exchange rate has no effect on the growth of the economy. The impact is positive and significant in the long-run. The appreciation of local currency value was indeed a boost for economic growth as per the findings of this study. This scenario is explained by the fact that although attempts have been made by the Central Bank of Nigeria to liberalize the foreign exchange market, the lack of export depth and autonomous foreign currency sources has forced the monetary authority to largely settle for managed float. The government is dependent of the crude oil and gas oil sector which although contributes about $10.29 \%$ of total real GDP (National Bureau of Statistics, 2016) and accounts for $70 \%$ of government revenue and 90\% of its foreign exchange earnings (Export.Gov, 2017. The price of crude oil export is exogenously determined by the Organization of Petroleum Exporting Countries (OPEC) and other players in the international oil market.

The import of these is that the economic growth of the country has been on the ascendancy throughout the study period notwithstanding the value of its currency. 
This is inconsistent with the predictions of the augmented Solow growth theory which predicts that the expensive nature of a country's exportable caused by an inflow of foreign currency through increased interest rate makes the value of domestic currency too high and consequently reduces the level of growth experienced in the current economic growth. Finally, although the unemployment rate is expected to contribute positively to economic growth is in line with Fuad (2011) in Jordan due to selectivity in the choice of job types by the nationals (manual jobs are shunned). The investigation by Oloni (2013) in Nigeria revealed positive but insignificant relationship between employment and growth. The postulation of Okun's law (1962) the result showed that unemployment rate had no impact with GDP in the short-run, but significantly contributed positively to economic growth in the long-run. This view holds that unemployment does not immediately impact economic growth in the short run, as people still have savings to augment their standard of living. However, as this savings is depleted, the standard of living is eroded, which thus reduces their disposable income and effective demand.

\section{CONCLUSION}

By itself, macroeconomic stability does not guarantee high rates of economic growth. Key institutional and structural measures are required in order to engender sustainable high rates of economic growth. These include trade liberalization, openness of governance, regulatory reform, financial sector reform, privatization, public service reform, inclusive growth programmes and institutional fight against corruption (Brian, Brown, Devarajan, \& Izquierdo, 2001). The result of this investigation into the nexus of the macroeconomic factors with economic growth is mixed and supports this position. The management of the five key macroeconomic variables is an arduous task even in developed economy. This is made more difficult because the Nigerian economy is largely dependent on crude oil for its foreign earnings. This reliance renders some of its fiscal and monetary policies prostrate to the vagaries of international trade and oil politics. The country experiences stagflation, a condition of simultaneous increases in both inflation and unemployment.

Given the preponderance of exogenous influence on the efficacy of both the fiscal and monetary policies, the government is enjoined to continue the diversification of the economic base of the country. Also, the Central Bank of Nigeria is enjoined to consider the continued adoption of the concept of inflation targeting to target the level of inflation that is consistent with the growth target of the economy which will ensure the stability of prices and consequently improved economic growth.

The study also recommends that beneficial policies with trickle down effects be deployed by the fiscal and monetary authorities. Social policy that leads to transfer of resources to the poor rural area is recommended, as this will aid their spending power which obviously impacted positively on their current income. 


\section{REFERENCES}

Adeniran, J., Yusuf, S, and Adeyemi, O. "The impact of exchange rate fluctuation on the Nigerian economic growth: An empirical investigation." International Journal of Academic Research in Business and Social Sciences, Vol. 4, No. 8, (2014): 224,-233

Agalega, Evans and Antwi Samuel. The impact of macroeconomic variables on Gross Domestic Product: Empirical evidence from Ghana. International Business Research, Vol. 6, No. 5. (2013): 108-116

Agwu, Charles. "Factors that contribute to economic growth in Nigeria." International Journal of Management and Commerce Innovations, Vol. 2, No. 2 (2014): 4.87- 4.95

Akeju, Kemi F. and Olanipekun Dayo. "Unemployment and economic growth in Nigeria." Journal of Economics and Sustainable Development, Vol. 5, No. 4, (2014): 138-144

Al-Habees, Mahmood and Rumman Mohammed Abu. "The relationship between unemployment and economic growth in Jordan and some Arab countries." World Applied Sciences Journal, Vol. 18, No. 5 (2012): $673-680$

Antwi, Samuel, Mills Ebenezer Fiifi Emire Atta and Zhao Xicang. "Impact of macroeconomic factors on economic growth in Ghana: A cointegration analysis." International Journal of Academic Research in Accounting, Finance and Management Sciences, Vol. 3, No. 1 (2013): 35- 45

Arewa, Ajibola and Nwakanma Prince. "Potential-real GDP and growth process of Nigerian economy: An empirical re-evaluation of Okun's Law." European Scientific Journal, Vol. 8, No. 9 (2012): 25-33

Azeez, B. and Kolapo Funso. "Effect of exchange rate volatility on macroeconomic performance in Nigeria." Interdisciplinary Journal of Contemporary Research in Business, Vol. 4, No. 1 (2012): 149-155

Babalola, O. Oladapo, Danladi Jonathan D. Akomolafe K. John, and Ajiboye, O. Paul. "Inflation, interest rates and economic growth in Nigeria." European Journal of Business and Management, Vol. 7, No. $3 \circ$ (2015): 91-102

Breusch, Trevor S and Pagan Adrian .R. "A simple test for heteroscedasticity and random coefficient variation." Econometrica, Vol. 47 (1979): 1287- 1294

Breusch, Trevor S. "Testing for autocorrelation in dynamic linear models." Australian Economic Papers, Vol. 17, (1978): 334-355. doi:10.1111/j.1467-8454.1978.tboo635.x.

Brian, Ames, Brown Ward, Devarajan, Shanta and Izquierdo, Alejandro. Macroeconomic Policy and Poverty Prepared by the International Monetary Fund and the World Bank, August (2001).

Brigitta, Jakob. "Impact of exchange rate regimes on economic growth." Undergraduate Economic Review, Vol. 12, No. 11 (2015): 1-22

Cassel, Karl Gustav. "Abnormal deviations in international exchanges." The Economic Journal, Vol. 28, (1918): 4.13-415

Central Bank of Nigeria (2017). Statistical Bulletin. Retrieved from www.cenbank.org/OUT/2015/ PUBLICATIONS/STATISTICS/2015/PartB/PartB.html

Chang-Shuai, Li, and ZI-Juan Liu. (2012). "Study on the relationship among Chinese unemployment rate, economic growth and inflation." Economic Growth and Finance, Vol. 1, No. 1 (2012): 1-6

Chugtai, Muhammad Waqas, Malik, Muhammad and Aftab, Rashid. "Impact of major economic variables on economic growth of Pakistan." Acta Universitatis Danubius, Vol. 11, No. 2 (2015): 94-106

Data (1992 - 2008): PSE Working Papers, No. 2012-05. 
Eichengreen, Barry. The Real Exchange Rate and Economic Growth. Commission on Growth and Development Working Paper No. 4 (2008).

Enders, Walter . Applied Econometric Time Series. New York: John Wiley, (1995).

Friedman, Milton (1956), The Quantity Theory of Money: A Restatement in Studies in the Quantity Theory of Money, edited by M. Friedman. Reprinted in M. Friedman The Optimum Quantity of Money (2005): $5^{1}$

Fuad, M. Kreishan. "Economic growth and unemployment: An empirical analysis." Journal of Social Sciences, Vol. 7, No. 2 (2011): 228-231

Gillman, Max, Harris M. Mark and Mátyás Laszlo. A non-linearity in the Inflation-Growth Effect. Central European University Department of Economics Working Paper 14/2000 (2000).

Hussain, Shahzad and Shahnawaz Malik. "Inflation and economic growth: Evidence from Pakistan." International Journal of Economics and Finance, Vol. 3, No. 5 (2011): 262-276

Jinzhao, Chen. Real Exchange Rate and Economic Growth: Evidence From Chinese Provincial

Johansen, Soren and Juselius Katarina. "Maximum likelihood estimation and inference on cointegration with Applications to the Demand for Money." Oxford Bulletin of Economics and Statistics, Vol. $5^{2}$ (1990): $169-210$

Johansen, Soren. "Statistical analysis of cointegration vectors." Journal of Economic dynamics and Control, Vol. 12 (1988): 231-254

Kaldor, Nicholas. The New Monetarism. (1970). Lloyd's Bank Review. July issue.

Keynes, John M. The General Theory of Employment, Interest and Money. New York: Macmillian, (1936).

Khan, Mohsin S. and Senhadji Abdelhaks. Threshold Effects in the Relationship between Inflation and Growth. IMF Staff Papers, No. 48, (2001): 1-21

Kira, Reuben Alex. "The factors affecting gross domestic product (GDP) in developing countries: The case of Tanzania. European Journal of Business and Management, Vol. 5, No. 4, (2013): 14,8-158

Lavinia, Stefania, Barbu Bogdan and Silvia Elena. "The impact of unemployment on economic growth in Romania, during the crisis." Academy of Economic Studies, Bucharest, Romanian Statistical Review, No., Vol. 61 No. 6, (2013): 32-4.

Limam, Ould Mohamed. "Consumer price index and economic growth: A case study of Mauritania 1990 2013." Asian Journal of Empirical Research, Vol. 5, No. 2 (2015): 16-23

Livio, Stracca Elitza Mileva and Maurizio, Michael The Real Exchange Rate and Economic Growth: Revisiting the Case Using External Instruments. European Central Bank Working Paper No.1921, (2016).

Lucas, Robert E. Jr., "on the mechanics of economic growth." Journal of Monetary Economics, Vol. 22, No. 1(1988): $3-42$

Madito, Oatlhotse and Khumalo, John "Economic growth - Unemployment nexus in South Africa: VECM approach." Mediterranean Journal of Social Sciences, Vol. 5, No. 2 (2014): 79-84.

Mallik, Girijasankar and Chowdhury Anis. "Inflation and economic growth: Evidence from South Asian Countries." Asian Pacific Development Journal, Vol. 8, (2001): 123-135

Mankiw, N. Gregory, Romer David and Weil, Davis. "A contribution to the empirics of economic growth." Quarterly Journal of Economics, No. 4, (1992): 4.07-437

Mbulawa, Strike. "Effect of macroeconomic variables on economic growth in Botswana." Journal of Economics and Sustainable Development, Vol. 6, No. 4 (2015): 105-122 
Myrdal, Gunnar.Asian Drama, An Inquiry into the Poverty of Nations. New York: Pantheon

National Bureau of Statistics, 2016) Retrieved from www.nigerianstat.gov.ng/

Nihat, Tas, Ali Hepsen, and Emrah Onder. "Analyzing macroeconomic indicators of economic growth using panel data." Journal of Finance and Investment Analysis, Vol. 2, No. 3 (2013): 41-53

Nwoye, Ugochukwu J., Obiorah Justina and Ekesiobi Chukwunonso. "Effect of Nigeria macroeconomic environment on the performance of the national economy: Implications. "International Journal of Academic Research in Business and Social Sciences, Vol. 5 , No. 7 (2015):42- $5^{1}$

Obrimah, Oghenovo. "Can interactions between financing and investment activities have dissimilar effects on inflation and exchange rates?" African Development Review, Vol. 27, No. 1 (2015): 41-51

Ojonye, Simon M. "The dynamics of inflation and its impact on the Nigerian economy: 1960 - 2012: An empirical analysis." Journal of Economics and Sustainable Development, Vol. 6, No. 6 (2015): 132-139

Okorontah, Chikeziem and Odoemena Ikenna Uchechukwu. "Effects of exchange rate fluctuations on economic growth of Nigeria." International Journal of Innovative Finance and Economics Research, Vol. 4, No. 2 (2016): 1-7

Okun, Arthur M. Potential GNP: Its measurement and significance in proceedings of the business and economic statistics section of the American Statistical Association. Alexandria, VA: American Statistical Association, (1962): 89-104

Oloni, Elizabeth Funlayo. "The impact of economic growth on employment in Nigeria." International Business and Management, Vol. 6, No. 1 (2013): 113-119

Omoke, Phillip Chimobi. "Inflation and economic growth in Nigeria." Journal of Sustainable Development, Vol. 3, No. 2 (2010): 159-166

Onakoya, Adegbemi B.O., Fasanya, Isiaq O. and Agboluaje, Mariam A. "Does monetary policy influence economic growth in Nigeria?" Asian Economic and Financial Review, Vol. 3, No. 5 (2013): 635-646

Qaiser, Munir and Kasim Mansur. "Non-linearity between inflation rate and GDP growth in Malaysia. Economics Bulletin, Vol. 29, No. 3 (2009): 1555-1569

Qin, Fei and Wang Qianyi. The research on inflation rate and unemployment rate in China. Proceeding of the International Conference on Social Science Research, (2013): 202-220

Rasaq, Akonji Danmola. "The impact of exchange rate volatility on the macro economic variables in Nigeria." European Scientific Journal, Vol. 9, No. 7 (2013): 152-165

Romer, Paul. "Growth based on increasing returns due to specialization." The American Economic Review, Vol. 77 , No. $2(1987): 56-62$

Rosoiu, Andreea. "The relation between unemployment rate and economic growth in USA." International Journal of Economic Practices and Theories, Vol. 4, No. 2 (2014): 162-167

Saymeh, Abdul Aziz and Orabi, Marwan Mohammad Abu. "The effect of interest rate, inflation rate, GDP, on real economic growth rate in Jordan." Asian Economic and Financial Review, Vol. 3, No. 3 (2013): 341354

Shatha, Abdel Khaliq, Thikraiat, Soufan, RubaAbu Shihab. "The Relationship between Unemployment and Economic Growth Rate in Arab Country. "Journal of Economics and Sustainable Development, Vol. 5 , No. $9(2014): 56-59$

Shuaib, I., Augustine O. Ekeria, and Ogedengbe Frank. "Impact of inflation rate on the economic growth in Nigeria." British Journal of Economics, Management, and Trade, Vol. 9, No. 3 (2015):11-15 
Solow, Robert. "A contribution to the theory of economic growth." The Quarterly Journal of Economics, Vol. 7०, No. 1 (1956): 65-94

Taylan, Taner Dogan. "Macroeconomic variables and unemployment: The case study of Turkey." International Journal of Economics and Financial Issues, Vol. 2, No. 1 (2012): 71-78

Thayaparan, A. "Impact of inflation and economic growth on unemployment in Sri Lanka: A study of time series analysis." Global Journal of Management and Business Research, Economics and Commerce, Vol. 13, No. 5 (2014): 45-54

Trading Economics .Nigeria Inflation Rate (2016). Available at http://www.tradingeconomics.com/ nigeria/blog.

Tridico, Pasquale. "The impact of the economic crisis on EU labour markets: A comparative perspective." International Labour Review, Vol.152, No. (2013): 175-190

Wicksell, K. Interest and prices: A Study of the causes regulating the value of money (1898). Retrieved from: http://www.mises.org/document/3124 